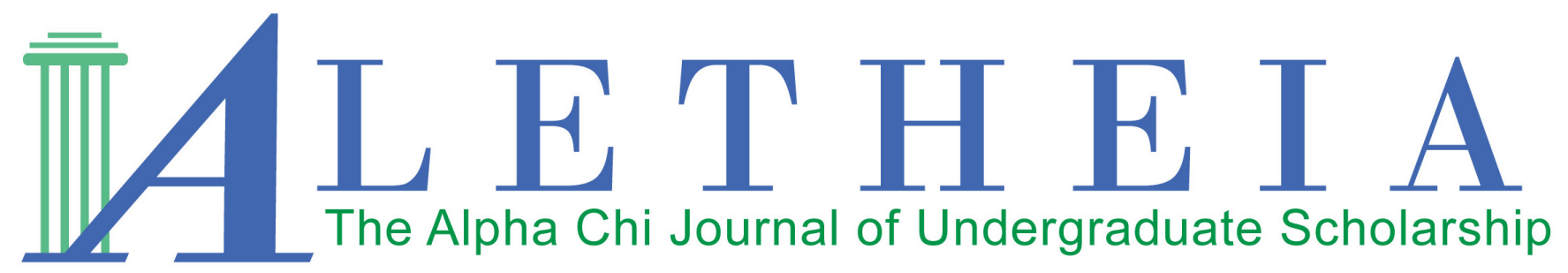

Volume 2 | Issue 2 | 2017

\title{
The Primo de Rivera Dictatorship and the Foundations of Authoritarianism in Spain (1923-1930)
}

\author{
Samuel B. Aly \\ Harding University \\ Arkansas Eta Chapter
}

Vol. 2(2), 2017

Article Title: The Primo de Rivera Dictatorship and the Foundations of Authoritarianism in Spain (1923-1930)

DOI: $10.21081 / \mathrm{AX} 0141$

ISSN: 2381-800X

Key Words: Spain, Fascism, Primo De Rivera, Authoritarianism, history

This work is licensed under a Creative Commons Attribution 4.0 International License.

Author contact information is available from the Editor at editor@alphachihonor.org.

\section{Aletheia-The Alpha Chi Journal of Undergraduate Scholarship}

- This publication is an online, peer-reviewed, interdisciplinary undergraduate journal, whose mission is to promote high quality research and scholarship among undergraduates by showcasing exemplary work.

- Submissions can be in any basic or applied field of study, including the physical and life sciences, the social sciences, the humanities, education, engineering, and the arts.

- Publication in Aletheia will recognize students who excel academically and foster mentor/mentee relationships between faculty and students.

- In keeping with the strong tradition of student involvement in all levels of Alpha Chi, the journal will also provide a forum for students to become actively involved in the writing, peer review, and publication process.

- More information and instructions for authors is available under the publications tab at www.AlphaChiHonor.org. Questions to the editor may be directed to editor@alphachihonor.org.

\footnotetext{
Alpha Chi is a national college honor society that admits students from all academic disciplines, with membership limited to the top 10 percent of an institution's juniors, seniors, and graduate students. Invitation to membership comes only through an institutional chapter. A college seeking a chapter must grant baccalaureate degrees and be regionally accredited. Some 300 chapters, located in almost every state, induct approximately 12,000 members annually. Alpha Chi members have been "making scholarship effective for good" since 1922.
} 


\title{
The Primo de Rivera Dictatorship and the Foundations of Authoritarianism in Spain (1923-1930)
}

\author{
Samuel B. Aly \\ Harding University \\ Arkansas Eta Chapter
}

\begin{abstract}
This paper seeks to examine the dictatorship of General Miguel Primo de Rivera (1923-1930) as the first installment of authoritarianism in Spain during the twentieth-century. The unique situation presented before the General, one of public disillusion and colonial impotence, required a new form of government to replace the inadequate turno system introduced almost fifty years earlier. In the convoluted political environment of the 1920s in Spain, Primo de Rivera took a distinct, circumstantial approach to the 'Moroccan problem' and ended the colonial rebellion within three years. By solving this protracted issue, the General proved the effectiveness of authoritarian rule for Spanish conservative factions, namely the army. Although the military man's administration eventually crumbled under the pressure of substantial policy issues, it was Primo de Rivera's dictatorship that set the stage for a stronger, more politically adept leader to assume absolute power. With the prevalence of fascist thought permeating Europe, Spain would soon be under the control of Francisco Franco and an authoritarian regime backed by precedence and strong ideology.
\end{abstract}

Key words: Spain, Fascism, Primo De Rivera, Authoritarianism, history

On September 13, 1923, General Miguel Primo de Rivera announced a military coup in Spain, replacing a rapidly crumbling liberal government under Prime Minister Manuel García Prieto. A few days later, King Alfonso XIII, whose parliamentary supporters were "thoroughly discredited," cautiously validated the regime. ${ }^{1}$ Despite the fact that many powerful groups within the military were traditionally conservative, it would be hard to argue that the previous administration's liberal platform caused the coup from a senior general of the Spanish army. In many ways, the Liberal and Conservative parties were closer to each other than either was

\footnotetext{
${ }^{1}$ James H. Rial, Revolution from Above: The Primo de Rivera Dictatorship in Spain, 1923-1930 (Fairfax, VA: George Mason University Press, 1986): 49-50.
}

to the new regime under General Primo de Rivera. The coup represented an altogether new form of conservative expression in the modern Spanish political arena, one that would shape the development of Spanish fascism in the 1930s. A decade before Francisco Franco rose to power, General Miguel Primo de Rivera demonstrated for Spanish military factions the effectiveness of authoritarian rule, a foundational tenet of fascism, and utterly discredited an old order of inept "professional politicians," liberal and conservative alike, by finding the solution to an escalating rebellion in the Spanish Protectorate of Morocco which so deeply humiliated the colonial power for years.

The origins of traditional Spanish conservativism relevant to Primo de Rivera's dictatorship reach as far 
back as the early nineteenth-century, although authoritarian rule was prevalent much earlier. The Crown and the Catholic Church had wielded authoritarian power for centuries in Spanish history until the introduction of the short-lived First Republic in 1873 . To say the era was a tumultuous time for Iberian civilization would be an understatement. Paralyzed by revolt against French rule, revolutions and coups, and profound economic instability early in the century, the vast majority of Spaniards found little in their national politic on which to base a common Spanish identity moving into the republican period.

There is little denying the effects of "the indomitable individualism of the Spanish character" on the state's history. ${ }^{2}$ Inheriting the legacy of the five Christian kingdoms from the Middle Ages and subsequent divisions, commoners took pride in their provincial identity, rather than a bond between people ruled by the central government. ${ }^{3}$ Regionalism became a foundational part of the Spanish psyche most quickly in Catalonia and the Basque Country, which were "not only linguistically and culturally distinct from the rest of Spain, but also possessed of a long tradition of independence."

Another phenomenon blended between Spanish culture and politics during the nineteenth-century is caciquismo. Originating from an indigenous word for "chief" in the New World, it came to represent the system of local bosses who controlled the lives and votes of common people for the parliamentary oligarchy after the Restoration. ${ }^{5}$ In 1874 , the beginning of the Restoration, caciquismo would be harnessed by newly appointed King Alfonso XIII and his allies to create "a profoundly inegalitarian society in which political and economic power were monopolized by a propertied oligarchy." 6 These elite were usually landowners of great local influence who received considerations from Parliament for their support. The system did effectively consolidate power between the two moderate parties through a system now known as the turno pacifico.

\footnotetext{
2 R.T. Desmond, "The New Regime in Spain," Foreign Affairs 2, no. 3 (March 1924): 459.

${ }^{3}$ Stanley Payne, Fascism in Spain (Madison: University of Wisconsin Press, 1999), 3-5.

${ }^{4}$ Charles J. Esdaile, Spain in the Liberal Age: From Constitution to Civil War, 1808-1939 (Malden, Massachusetts: Blackwell Publishers, 2000): 170.

${ }^{5}$ Desmond, "The New Regime in Spain," 458.

${ }^{6}$ Esdaile, 141.
}

The turno, instituted by Antonio Cánovas del Castillo in January 1876, was a mutual agreement that peacefully exchanged control of the government between the Liberal and Conservative parties. ${ }^{7}$ Both groups were relatively moderate, striving for reform within the constitutional monarchy and desiring a long period of peace and stability that had eluded Spain for the better part of a century. Although relatively simple goals in a modern context, the validation of the established system and thus, political stability, were indeed platforms that needed to be defended. Political groups and social trends that developed or reinvented themselves to fit contemporary Spain during the period from the Restoration to the Dictatorship-Anarcho-Syndicalists, Separatists, Communists - favored other means of government entirely. The moderate groups desired to keep "such undesirables" out of power while retaining the façade of an electoral system. $^{8}$

Cánovas facilitated the turno through caciquespragmatically, through fixed elections. Local caciques orchestrated electoral misrepresentation either by instructing their constituents on how to vote, or, in the case of insubordination, using more direct methods of intimidation and electoral fraud. ${ }^{9}$ The turno successfully stabilized Spanish politics at a cost of economic equality. This system continued for over fifty years, until it was interrupted by the coup in 1923 .

One final aspect of Spain's political tradition relating to the dictatorship is the long history of Spanish praetorianism, essentially military intervention in political affairs. Though many military coups took place during the wide-swinging pendulum of nineteenth-century politics, circumstances surrounding the First Spanish Republic and subsequent Restoration from 1873 to 1876 dictated the place of the army on the political continuum. The military became a necessary half of "the alliance of power and privilege that came to constitute the modern Right" in Spain. ${ }^{10}$ Until 1923, praetorianism was ideologically tied to the conservative side of the political spectrum. Before the Restoration and towards the end of the Dictatorship in the late-1920s, it seems that the military manifested itself in Spanish society as a nebulous political entity, albeit one with a tremendous amount of power.

\footnotetext{
${ }^{7}$ Esdaile, 148.

${ }^{8}$ Desmond, "The New Regime in Spain," 458.

${ }^{9}$ Esdaile, 148-9.

${ }^{10}$ Ibid, 143.
} 
When examining General Primo de Rivera and his Military Directory, it is critical to recognize the influence of the army as an independent political body.

For the most part, the country lacked an organized expression of public sentiment for several decades prior to the coup due to caciquismo and repression from Parliament. In 1920, Catalan politician Emilio Riu wrote, "All Spanish political life is organized so that [public opinion], if it exists, does not manifest itself, and if it is manifested, it is falsified."11 The confluence of forces that weakened Spain as it arrived to the twentieth-century also condemned the majority of the Spanish population to a juvenile, underdeveloped sense of citizenship that relied as much on regionalism and the orders of their caciques as it did on personal self-interest. Nonetheless, two main positions of the Spanish public which can be accurately represented are the vain waste of resources on colonialism in Morocco and general disillusionment with the trend of the incompetent, "professional politician" under the turno system. ${ }^{12}$

Regionalism and caciquismo presented major influences on General Primo de Rivera's policy upon gaining power. One of his stated goals was to unify the nation. The central authorities of Spain feared that regionalism, a hallmark of Spanish culture, could eventually become full-fledged revolutionary separatism. Often, the two were erroneously associated in the broad, exaggerated reform of the Military Directory's early days, especially in reference to Catalan and Basque culture. ${ }^{13}$ The General declared, "Regionalist sentiments are inconsistent with a Grand Fatherland." 14 Primo de Rivera's solution for this separatist opposition to the conceptualization of a Spanish nation was a harsh, imprecise form of censorship, which succeeded under Cánovas in the late nineteenth-century and would prove effective again under Primo de Rivera.

\footnotetext{
${ }^{11}$ Emilio Riu, "La organización de la decadencia en España," Revista Nacional de Economía 25 (1920): 470.

12 Desmond, "The New Regime in Spain," 466.

${ }^{13}$ R.T. Desmond, "Dictatorship in Spain," Foreign Affairs 5, no. 2 (January 1927): 276-292.

${ }^{14}$ Shlomo Ben-Ami, "The Dictatorship of Primo de Rivera: A Political Reassessment," Journal of Contemporary History 12, no. 1 (January 1977): 67.
}

The system established was the Military Directory, which consisted of eight generals and one admiral. ${ }^{15}$ The "energetic display" demonstrated by the General and his Directory in the early months provided hope for a new type of politician to represent the Spanish public. ${ }^{16}$ His manner of implementing reform deserves a reminder. Primo de Rivera did not achieve success constitutionally or even with the explicit support of the king, a fact which exposes early undercurrents of authoritarian success in Spain. Even though this was not his inherent motivation, Primo de Rivera did circumvent traditional Spanish constitutional monarchy by instituting a military takeover. ${ }^{17}$ Furthermore, his coup negated one of the most foundational, longstanding tenets of the moderate-Conservative platform: belief in the supreme authority of the Bourbon monarchy. ${ }^{18}$ Even though the General gained Alfonso's support within days of the coup, the takeover was indeed unsolicited.

One of the most visible manifestations of previous regimes' ineptitude was the ongoing failure to define or implement a successful strategy for colonial subjugation of Morocco. For over a decade, Spanish forces had been struggling to retain control of the Western Sector of the colony both militarily and politically. The Spanish Army in Morocco, known as africanistas, faced a territory that was unmapped, barely sustainable from a colonizer's perspective, and full of unfriendly, warlike tribes. ${ }^{19}$ Surely ongoing rebellion in Morocco was one of the main reasons that recently deposed Prime Minister García Prieto seemed more relieved than affronted to have power so roughly seized from his grasp. After observing Primo de Rivera's swift and decisive actions in the opening days of the coup, Prieto stated, "I have one more saint to commend myself to, Saint Miguel Primo de Rivera, because he has lifted the weight of government from my shoulders." 20

\footnotetext{
${ }^{15}$ Desmond, "The New Regime in Spain," 466.

${ }^{16}$ Rial, 55.

${ }^{17}$ Desmond, "Dictatorship in Spain," 276.

${ }^{18}$ Payne, Spanish Conservatism 1824-1923, 777.

${ }^{19}$ Susana Sueiro Seoane, "Spanish Colonialism during Primo de Rivera's Dictatorship," trans. Jessica Brown, Mediterranean Historical Review 13, no. 1-2 (1998): 49.

${ }^{20}$ Gabriel Maura Gamazo and Mechor Fernández Almagro, Por qué cayó Alfonso XIII (Madrid: Ambos Mundos, 1948), 435, quoted in Rial, 55.
} 
If anyone were to be able to solve the Moroccan problem, it would be General Primo de Rivera. For years, he had been publically advising abandonment of the North African Protectorate- echoing popular sentiment that securing the dry, fruitless land in and around the Rif Mountains was costing much more in economic and human capital than it could ever recompense. ${ }^{21}$ In truth, this was a rather idealistic approach. Upon his self-appointment as dictator, the necessities of consolidating power forced Primo de Rivera to change his position on Morocco from abandonment in order to face the unpleasant realities of the situation in the Rif.

What were the forces at play in the Moroccan problem? Why did Spanish politicians stubbornly refuse abandonment of the Protectorate? Surely, the Spanish public would have overwhelmingly supported the decision. The most consequential fetter shackling Spain to North Africa was the nation's desperate ambition for a more important position in modern Europe. Successful colonial revolutions in America during the early-to-mid-nineteenth-century destroyed any credibility that the Spanish Empire had left. Culminating in the Disaster of 1898, the empire that had once ruled the world finally collapsed with the cession of Guam, Puerto Rico, and the Philippines to the United States, and the independence of Cuba. This monumental collapse relegated Spain to a "second-class European power," an indignity the nation was eager to disprove. ${ }^{22}$

This commonly perceived sense of inferiority was one unpalatable to the Spanish military and its network in national government. At the beginning of his regime, the Dictator stood in transition between the two poles of Spanish opinion on Morocco. One side was composed of africanistas and many, but not all, upper class factions of Spanish society who were loath to admit defeat and retreat in any manner. Opposing the military elite was the majority of Spanish society, who had seen the devastating defeat at Annual in 1921 as resulting from greedy mismanagement and incompetence by the army as a whole. In some ways, the more popular opinion was correct. For years, the parliamentary oligarchy had avoided threats of revolt from Spanish military through methods of appeasement - continuing to pay wages to insupportable amounts of low-to-mid-ranking officers

\footnotetext{
${ }^{21}$ Seoane, 48-9.

${ }^{22}$ Esdaile, 186.
}

in order to retain their support politically. ${ }^{23}$ In fact, the Moroccan affair began in 1909 partially out of Maura's necessity for an "outlet for congested cadres," whose idle hands had the propensity for stirring up trouble. ${ }^{24}$ However unsuccessful in the early years of the Protectorate, in some ways involvement in Morocco released a quickly deteriorating Parliament from the direct influence of Spanish military, the africanistas; it was an intriguing distraction from the political problems on the home front.

Primo de Rivera quickly shifted his approach on the situation from idealistic to pragmatic upon assuming power in 1923 . The actions taken by the General while fronting the Moroccan problem clearly illustrate one of his most lucid beliefs, if not a true political ideology: a reliance on his own intuition in whatever circumstances may arise, commonly known as intuicismo. Primo de Rivera's military upbringing impressed a different set of values and certainly a different set of skills. He was "an amateur politician who believed fervently in his "intuition." ${ }^{25}$ This played heavily on the manner and style of his actions in Morocco, as well as those of his officers and high-ranking officials in the military.

Warfare escalated daily. Operating in the Spanish-held Western Sector of Morocco, Riffi leader Abd el-Krim had used the Spanish humiliation at Annual in 1921 as a rallying point to consolidate his power among the region's previously fragmented tribes. ${ }^{26}$ Lacking military support from the French, who occupied the Eastern Sector, the Dictator never defined an absolute, concrete policy for Morocco. Using his own intuition, he shifted approaches through circumstantial decision-making. After a threat on the Eastern Zone forced French military leaders into action, Primo de Rivera, now acting as High Commissariat in Morocco, planned a joint Franco-Spanish amphibious operation on the Bay of Alhucemas that would lead straight to the heart of the Riffi base of operations. ${ }^{27}$ The operation, which took place on September

\footnotetext{
${ }^{23}$ Desmond, "The New Regime in Spain," 462.

${ }^{24}$ R.T. Desmond. "The New Regime in Spain," Foreign Affairs 2, no. 3 (March 1924): 461.

25 Ben-Ami, 65.

${ }^{26}$ Seoane, 50.

${ }^{27}$ Shannon E. Fleming and Ann K. Fleming, "Primo de Rivera and Spain's Moroccan Problem, 1923-27," Journal of Contemporary History 12, no. 1 (January 1977): 89-91, JSTOR.
} 
8,1925 , was an immediate success. ${ }^{28}$ In May 1926, imperial progress forced Abd el-Krim into unconditional surrender, thus solving the most characteristic issue at work against the Spanish in the Moroccan problem.

Primo de Rivera's conduct leading up to the Alhucemas invasion is exemplary of the greater trend of intuicismo present in his administration. The significance of this comes from greater context. The Dictator's actions were not necessarily predictable because they were not politically motivated. Whereas before the coup, Spanish conservatives had been more or less bound to common political goals (especially, retaining the authority of the monarchy), now General Primo de Rivera and by extension the military were bound only by self-interest. They were unrestrained by the common trappings of traditional Spanish conservativism.

With this interpretation of Dictator's approach to major concerns, the reasons behind the success of Francisco Franco and fascism only a decade later become more apparent. The origins of Primo de Rivera's regime lie in complete subversion of the constitutional system and the Conservative party therein - a fact that was plain to see for the Spanish people. More privately, the coup defied the King, who had later given his affirmation of the regime out of necessity. ${ }^{29}$ Essentially, the General introduced the reality of authoritarian rule to Spain in a time where similar styles of government developed quickly in Italy and Germany.

Was authoritarian rule effective for Primo de Rivera? The Directory's crowning achievement was victory in Morocco. Under the Dictator, Spain finally found a path to national modernization. The administration "developed industry, particularly power and mining, reequipped the railways, built excellent roads . . . [and] reduced unemployment (like all dictators) through public works." ${ }^{30}$ The regime foundered within seven years, but this had much to do with the ailing figurehead's obvious lack of political skill. The fact that his greatest success was a military operation was not a coincidence. He was, by training and character, a military man. The Great Depression in 1929 placed great strain on Primo de Rivera, who was ill equipped to handle such a monumental

\footnotetext{
${ }^{28}$ Fleming and Fleming, 91.

${ }^{29}$ Desmond, "The New Regime in Spain," 465.

${ }^{30}$ James Cleugh, Spain in the Modern World (New York: Alfred A. Knopf): 96.
}

problem that confounded even some of the most economically adept politicians. At last, in 1930, the regime folded under a mountain of debt. The General resigned upon request of the King and dutifully exiled himself to Paris, where he died two months later. ${ }^{31}$

It would be remiss to exclude Primo de Rivera's relationship with Italian fascism. During his first foreign visit as dictator, the General spoke highly of Mussolini's policies, and King Alfonso XIII enjoyed comparisons between the two. ${ }^{32}$ There is no doubt that additional trans-Mediterranean networking and ideological influence were possible, although the strength of the effects that the growing Italian fascist system had on Primo de Rivera's policies remained minimal. In fact, the true value of comparing the two is the juxtaposition between the systems, which provides stark contrast for the historian. The regimes were disparate in style and origin of power. Whereas Mussolini's fascist approach originally worked within the constitutional monarchy, General Primo de Rivera's military coup superseded the Spanish Constitution and wrought a new governmental structure to establish a platform. ${ }^{33}$ General Primo de Rivera's system was not fascist in origin or in practice. However, the regime did demonstrate the potency of authoritarianism in Spain, albeit a diluted form.

As a system of government, the Military Directory was a failure. In many ways, it also failed as a consolidation of conservative factions in Spain. Quite ironically, Primo de Rivera often struggled gaining the support of the military. ${ }^{34}$ However, he did settle the most pressing issue of 1923: rebellion in Morocco, a feat that previous Parliaments were unable to achieve. The style in which the Dictator accomplished this task was not available to politicians within a constitutional monarchy who were motivated by self-interest. The Spanish public tired of inept politicians, fraudulently elected through a system of caciquismo and failed to usher in an era of modernization. With time and a popular sense of hope on his side, the General utilized his intuición to seize opportunities that ended the war. He remained unbound by partisan interference. He had complete authority.

\footnotetext{
${ }^{31}$ Esdaile, 280.

${ }^{32}$ Ben-Ami, 66.

${ }^{33}$ Desmond, "The New Regime in Spain," 465.

${ }^{34}$ R.T. Desmond, "The Aftermath of the Spanish

Dictatorship," Foreign Affairs 9, no. 2 (January 1931): 302.
} 
To draw a direct connection between Primo de Rivera and Francisco Franco - the supporters of the two regimes and their philosophical justification for authoritarian rule - would be to overlook a critical period of political development. In fact, it was during the republican era following the fall of Primo de Rivera's dictatorship that the political consequences of the regime were fully revealed. King Alfonso XIII's close ties with the previous dictatorship did nothing to alleviate this rocky beginning to the Second Republic. Republican figures like Melquíades Álvarez seized upon the opportunity to disparage Primo de Rivera's "illegal incarnation of an arbitrary and factious power" founded in "military disloyalty" and supported by "the unshakeable confidence of the Crown." 35 Growing discontent and overwhelming republican victories in the elections of April 1931 forced Alfonso to flee the country in exile.

Such shocking changes only compounded the upheaval of traditional conservative groups in Spain. General Primo de Rivera's coup had only served to weaken the political relevancy of the monarchy. Less than a decade afterwards, a new era of republican government rendered the Crown politically obsolete and powerless.

In 1923, the Spanish people accepted the regime of General Miguel Primo de Rivera. He appeared as a non-traditional politician who had the power and motivation to fix the recurrent problems of Spain in the modern era. With the coup, the General bypassed a parliamentary oligarchy of incompetent and self-serving "professional politicians" to make assertive decisions on those problems, especially the war in Morocco. Assuming control in the Protectorate was only possible through authoritarian rule, which Primo de Rivera demonstrated by acting swiftly and effectively. This was not a lesson Spanish leaders would forget. Through Primo de Rivera's dictatorship, authoritarianism became a reality in Spain. Within a decade, another man would wield power in a similar manner-with much different results.

\footnotetext{
${ }^{35}$ Fernando Suárez González, Melquíades Álvarez: El Drama Del Reformismo Español (Madrid: Marcial Pons Ediciones De Historia, 2014): 81.
}

\section{Bibliography}

Ben-Ami, Shlomo. "The Dictatorship of Primo de Rivera: A Political Reassessment." Journal of Contemporary History 12, no. 1 (January 1977): 65-84.

Cleugh, James. Spain in the Modern World. New York: Alfred A. Knopf, 1953.

Desmond, R. T. "The New Regime in Spain." Foreign Affairs 2, no. 3 (March 1924): 457-473.

- "Dictatorship in Spain." Foreign Affairs 5, no. 2 (January 1927): 276-292.

. "The Aftermath of the Spanish Dictatorship." Foreign Affairs 9, no. 2 (January 1931): 297-309.

Ehrlich, Charles E. "The Lliga Regionalista and the Catalan Industrial Bourgeoisie." Journal of Contemporary History 33, no. 3 (July 1998): 399-417.

Esdaile, Charles J. Spain in the Liberal Age: From Constitution to Civil War, 1808-1939. Malden, Massachusetts: Blackwell Publishers, 2000.

Fleming, Shannon E. and Fleming, Ann K. "Primo de Rivera and Spain's Moroccan Problem, 1923-27.” Journal of Contemporary History 12, no. 1 (January 1977): 85-99. JSTOR.

González, Fernando Suárez. Melquíades Álvarez: El Drama Del Reformismo Español. Madrid: Marcial Pons Ediciones De Historia, 2014. JSTOR.

Jackson, Gabriel. The Spanish Republic and the Civil War 1931-1939. Princeton: Princeton University Press, 1965.

Payne, Stanley G. Falange: A History of Spanish Fascism. Stanford: Stanford University Press, 1961.

. Fascism in Spain 1923-1977. Madison: University of Winsconsin Press, 1999.

_. "Spanish Conservatism 1834-1923." Journal of Contemporary History 13, no. 4 (October 1978): 765 789. JSTOR.

Rial, James H. Revolution from Above: The Primo de Rivera Dictatorship in Spain, 1923-1930. Fairfax, Virginia: George Mason University Press, 1986.

Riu, Emilio. "La organización de la decadencia en España." Revista Nacional de Economía 25 (1920): 467-474. Hemeroteca Digital.

Seoane, Susana Sueiro. "Spanish Colonialism During Primo de Rivera's Dictatorship.” Trans. Jessica Brown. Mediterranean Historical Review 13, no. 1-2 (1998): 48-64. JSTOR.

Thomas, Hugh. The Spanish Civil War. New York: Harper Brothers, 1961.

Whitaker, Arthur P. Spain and the Defense of the West: Ally and Liability. New York: Harper Brothers, 1961. 